\title{
POU5F1 wt Allele
}

National Cancer Institute

\section{Source}

National Cancer Institute. POU5F1 wt Allele. NCI Thesaurus. Code C61141.

Human POU5F1 wild-type allele is located in the vicinity of $6 \mathrm{p} 21.31$ and is approximately 6 $\mathrm{kb}$ in length. This allele, which encodes POU domain, class 5, transcription factor 1 protein, plays a role in the regulation of tissue-specific gene expression in lymphoid and pituitary differentiation and in early mammalian development. 